\title{
Peptic ulcer and gastric secretion in patients with liver disease
}

\author{
SOAD TABAQCHALI ${ }^{1}$ AND A. M. DAWSON
}

From the Medical Unit, Royal Free Hospital, London

SYNOPSIS The overall incidence of peptic ulcer in 290 patients with portal cirrhosis was $11 \cdot 3 \%$. The incidence was the same in male and female patients whether or not the patient had an alcoholic history and whether or not they had had a portacaval anastomosis.

No abnormality of gastric secretion was observed in patients with hepatic cirrhosis except after a portacaval anastomosis when the basal gastric acid secretion increases, but there is no concomitant increase in response to maximum histamine stimulation. In addition the gastric contents both at night when fasting and during the day on a standardized diet were more acid in patients who had undergone a portacaval anastomosis than in patients with uncomplicated hepatic cirrhosis.

Patients with hepatic cirrhosis may bleed into the gut not only from oesophageal varices, but also from a chronic peptic ulcer or erosive gastritis (Palmer and Brick, 1953). It may thus be difficult to pinpoint the exact cause of gastrointestinal haemorrhage in patients with hepatic cirrhosis, especially as it is generally agreed that there is a high incidence of peptic ulcer in such patients. But the reported frequency of this association varies widely (Koide, Texter, and Borden, 1958) and most of the series have been reported from North America where cirrhosis is usually associated with alcoholism so that it is often not clear whether the important factor is the liver disease or the alcoholism. More recently it has been suggested that ulcers occur even more frequently following a portacaval anastomosis operation (Clarke, Ozeran, Hart, Gruze, and Crevling, 1958). This has stimulated the re-investigation of the effects of such operations on gastric secretion in dogs and it has been confirmed that following such an operation the acid secretion from a Heidenhain pouch is greatly increased (Clarke et al., 1958); but the results of gastric secretory studies in patients with hepatic cirrhosis have been conflicting (Ostrow, Timmerman, and Gray, 1960; Clarke, Costarella, and Ward, 1959a; Bendett, Fritz, and Donaldson, 1963).

It thus seemed desirable to try to establish whether there is an increased incidence of peptic ulcer in patients with hepatic cirrhosis not associated with alcoholism, for this form predominates in Great Britain. Furthermore, gastric secretion was studied

'Supported by Dowager Countess Peel Research Fund.

4 in these patients to see if any alteration might give a clue as to the cause of the increased incidence of peptic ulcer which was found in the patients with liver disease.

\section{PATIENTS STUDIED AND METHODS}

The notes of 200 consecutive patients with non-alcoholic portal cirrhosis seen between 1957 and 1960 were reviewed. Most of the patients had had a barium meal and certainly all those who complained of any indigestion. Only $x$-ray evidence was used to assess the presence or absence of a chronic peptic ulcer. There were 90 men and 110 women in this series and 58 of these patients were below the age of 35 years. During the same period 55 patients with portal cirrhosis and alcoholism were seen ( 45 men and 10 women). In addition 35 patients who had had a portacaval anastomosis for gastrointestinal haemorrhage secondary to portal hypertension one to eight years previously and 42 patients with primary biliary cirrhosis were reviewed. The diagnoses were made by clinical, biochemical, and where possible histological criter ia.

GASTRIC SECRETORY STUDIES Gastric secretion under basal conditions and following maximum histamine stimulation (Kay, 1953) was measured in 12 patients with portal cirrhosis, in nine patients with a portacaval anastomosis, in two patients before and after portacaval anastomosis, and in one patient who was receiving oral neomycin. In one additional patient with a portacaval anastomosis only the basal gastric secretion was measured. Thirteen patients with primary biliary cirrhosis and nine subjects who were convalescing from a variety of nongastrointestinal disorders were also studied. Samples of gastric juice were also obtained hourly for 24 hours from 
11 patients with portal cirrhosis, seven patients with a portacaval anastomosis, seven patients with primary biliary cirrhosis, and seven normal subjects. In all these studies the tip of the tube was shown radiologically to be at the junction of the body and the antrum of the stomach. During the 24-hour period of gastric sampling, a standardized series of light meals and milk drinks was prescribed (Atkinson and Henley, 1955). The $p H$ of the aspirated gastric contents was measured with a glass electrode and the acidity of the samples was estimated by titrating with $\mathrm{N} / 100$ sodium hydroxide to $\mathrm{pH} 7$.

\section{RESULTS}

INCIDENCE OF PEPTIC ULCER The overall incidence of peptic ulcer in the 290 patients with portal cirrhosis was $11 \cdot 3 \%$ (Table I). There was no difference in the incidence of peptic ulcer in those patients whose cirrhosis was or was not associated with alcoholism or who had had a portacaval shunt. Two patients included in the portacaval group had a duodenal ulcer before the operation, but are included so as not to give an unnecessary bias against the group. The normal preponderance of peptic ulcers in men was not seen in these patients with portal cirrhosis and the male to female ratio when corrected for the slight preponderance of men in the group was $0.9: 1$ for gastric ulcers and $1 \cdot 1: 1$ for duodenal ulcers. The incidence was similar in the men above and below the age of 35 years, but in women over the age of 35 years there was a five-fold increase, the incidence being $14.9 \%$ (Table II). The ratio of duodenal to gastric ulcer of $3.5: 1$ for men was similar to that of $2 \cdot 8: 1$ for women. Peptic ulcer was extremely frequent in patients with primary biliary

\section{TABLE II}

EFFECT OF AGE AND SEX ON OCCURRENCE OF PEPTIC ULCER IN ALL PATIENTS WITH HEPATIC CIRRHOSIS

\begin{tabular}{|c|c|c|c|c|c|}
\hline \multirow[t]{2}{*}{ Sex } & \multirow{2}{*}{$\begin{array}{c}\text { Age in } \\
\text { Years }\end{array}$} & \multirow{2}{*}{$\begin{array}{c}\text { No of } \\
\text { Patients }\end{array}$} & \multicolumn{2}{|c|}{ Peptic Ulcer } & \multirow{2}{*}{$\begin{array}{l}\text { Expected \% } \\
\text { Incidence Range of } \\
\text { Decades (Doll, 1952) }\end{array}$} \\
\hline & & & Number & $\%$ & \\
\hline Male & $\begin{array}{l}<35 \\
>35\end{array}$ & $\begin{array}{r}26 \\
128\end{array}$ & $\begin{array}{r}4 \\
14\end{array}$ & $\begin{array}{l}15.4 \\
10.9\end{array}$ & $\begin{array}{r}0.5-3.4 \\
7-9.6\end{array}$ \\
\hline Female & $\begin{array}{l}<35 \\
>35\end{array}$ & $\begin{array}{l}42 \\
94\end{array}$ & $\begin{array}{r}1 \\
14\end{array}$ & $\begin{array}{r}2.4 \\
14.9\end{array}$ & $\begin{array}{c}0.9 \\
2-6\end{array}$ \\
\hline
\end{tabular}

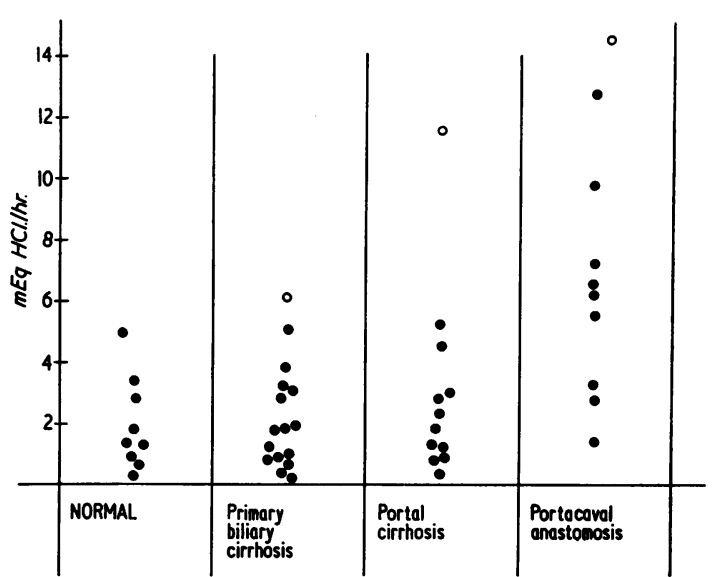

FIG. 1. Basal acid secretion ( $m E$ E./hr.) in normal persons and in patients with liver disease. $O=$ duodenal ulcer.

cirrhosis and was present in 11 of the 36 women and three of the six men with this disorder.

BASAL ACID SECRETION (FIG. 1) The normal subjects secreted up to $5 \mathrm{mEq} . / \mathrm{HCl} / \mathrm{hr}$. and this range is comparable to that reported by Kay (1953), Baron (1963), and Grossman, Kirsner, and Gillespie (1963). Two of the 12 patients with portal cirrhosis and seven of the 10 patients with a portacaval anastomosis had a raised basal acid secretion. All the $\mathbf{1 6}$ patients with primary biliary cirrhosis had a normal basal acid output.

MAXIMUM ACID OUTPUT (FIG. 2) The normal subjects produced up to $40 \mathrm{mEq} . / \mathrm{HCl} / \mathrm{hr}$. under maximum histamine stimulation. This was comparable to the range reported by Kay (1953), Bruce, Card, Marks, and Sircus (1959), Bock, Richards, and Witts, (1963), and Baron (1963). Nearly all the patients with liver disease had a normal maximum secretion and only two of the patients with portal cirrhosis, two with primary biliary cirrhosis, and three of those who had had a portacaval anastomosis fell above this

TABLE I

INCIDENCE OF PEPTIC ULCER IN PATIENTS WITH HEPATIC CIRRHOSIS

\begin{tabular}{|c|c|c|c|c|c|c|}
\hline Liver Disease & Sex & $\begin{array}{c}\text { No. of } \\
\text { Patients }\end{array}$ & Duodenal Ulcer & Gastric Ulcer & Total & $\%$ \\
\hline Non-alcoholic & $\begin{array}{l}\mathbf{F} \\
\mathbf{M}\end{array}$ & $\begin{array}{r}110 \\
90\end{array}$ & $\begin{array}{l}9 \\
9\end{array}$ & $\begin{array}{l}4 \\
1\end{array}$ & $\left.\begin{array}{l}13 \\
10\end{array}\right\}$ & 11.5 \\
\hline Alcoholic & $\begin{array}{l}\mathbf{F} \\
\mathbf{M}\end{array}$ & $\begin{array}{l}10 \\
45\end{array}$ & $\frac{1}{3}$ & $\frac{1}{2}$ & 5$\}$ & $9 \cdot 1$ \\
\hline Portacaval anastomosis & $\begin{array}{l}\mathbf{F} \\
\mathbf{M}\end{array}$ & $\begin{array}{l}16 \\
19\end{array}$ & $\begin{array}{l}2 \\
2\end{array}$ & 1 & $\left.\begin{array}{l}2 \\
3\end{array}\right\}$ & $14 \cdot 3$ \\
\hline Total & $\begin{array}{l}\mathbf{F} \\
\mathbf{M}\end{array}$ & $\begin{array}{l}136 \\
154\end{array}$ & $\begin{array}{l}11 \\
14\end{array}$ & $\begin{array}{l}4 \\
4\end{array}$ & $\begin{array}{l}15 \\
18\end{array}$ & $\begin{array}{l}11.0 \\
11.7\end{array}$ \\
\hline Grand total & $\mathbf{M} \& \mathbf{F}$ & 290 & 25 & 8 & 33 & $11 \cdot 3$ \\
\hline
\end{tabular}




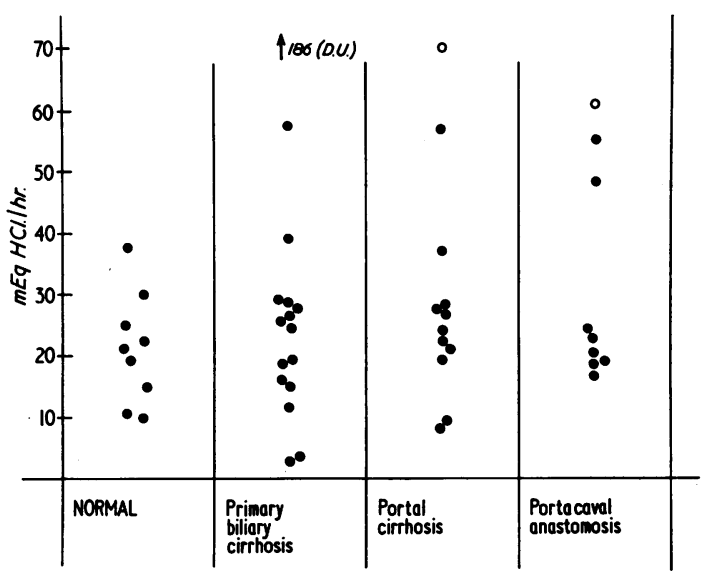

FIG. 2. Maximal acid secretion ( $m E q . / h r$.$) in normal$ persons and in patients with liver disease. $\mathrm{O}=$ duodenal ulcer.

range: this included the three patients with a duodenal ulcer.

TWENTY-FOUR-HOURLY $p H$ READINGS (TABLE III) There was great variation between patients within the groups, but the patients with a portacaval anastomosis had a more acid stomach both during

TABLE III

HOURLY INTRAGASTRIC $p$ H DURING 24 HOURS

\begin{tabular}{|c|c|c|c|}
\hline \multirow[t]{2}{*}{ Patients } & \multirow{2}{*}{$\begin{array}{l}\text { No. of } \\
\text { Patients }\end{array}$} & \multirow{2}{*}{$\begin{array}{l}\text { No. of } \\
\text { Observations }\end{array}$} & $\%$ Readings below \\
\hline & & & $\mathrm{p} H 2.5 \quad \mathrm{p} H 1.5$ \\
\hline
\end{tabular}

Night (12 a.m.-8 a.m.)

Controls

Portal cirrhosis

Portacaval anastomosis

7
7
11
7

$\begin{array}{lll}61 & 30 & 20 \\ 59 & 42 & 17 \\ 89 & 31 & 26 \\ 61 & 76 & 52\end{array}$

Day (9 a.m.-11 p.m.)

Controls

Primary biliary cirrhosis

Portal cirrhosis

Portacaval anastomosis

7
7
11
7

94
104
146
101

$\begin{array}{rr}22 & 8 \\ 38 & 12 \\ 24 & 16 \\ 54 & 32\end{array}$

the day when gastric secretions were stimulated by food and at night when the stomach was empty.

EFFECT OF A PORTACAVAL ANASTOMOSIS OPERATION Two patients were studied before and after operation. One had an established duodenal ulcer before the operation; this was associated with a high basal secretion of $7 \cdot 2 \mathrm{mEq} . / \mathrm{HCl} / \mathrm{hr}$. and a raised maximum histamine secretion of $\mathbf{7 0 . 2} \mathrm{mEq}$./hr. Neither level changed after the operation when they were 9.0 and $60 \cdot 1 \mathrm{mEq} . / \mathrm{HCl} / \mathrm{hr}$. respectively. However, before operation the basal acid output of a 15-year-old boy was $1.4 \mathrm{mEq} . / \mathrm{HCl} / \mathrm{hr}$. and this rose to $7.2 \mathrm{mEq} . / \mathrm{HCl} /$ $\mathrm{hr}$. after a portacaval anastomosis operation. The maximum acid output did not change, being 21.8 $\mathrm{mEq} . / \mathrm{HCl} / \mathrm{hr}$. before and $18.4 \mathrm{mEq} . / \mathrm{HCl} / \mathrm{hr}$. afterwards.

EFFECT OF THE NEOMYCIN Oral neomycin ( 4 g. daily) had no effect on the abnormal gastric secretory pattern of one patient with a portacaval anastomosis.

\section{DISCUSSION}

The clinical incidence of peptic ulcer varies in different countries, and the best control study with which to compare our results is that for the general population of Great Britain quoted by Doll (1952). With the small numbers of patients in our series, slight differences in incidence will clearly not be significant and in fact there is no definite evidence of an increased incidence of peptic ulcer in our male patients over the age of 34 , for the incidence in the general population in that age group is nearly $10 \%$ (Table II). However, there is suggestive evidence from the results of the few male patients below the age of $\mathbf{3 5}$ and far more impressive evidence from the women. The complete obliteration of the normal preference for peptic ulcer to attack males is the most remarkable feature of this survey. Normally the sex ratio of duodenal ulcers to male is $6 \cdot 8: 1$ while the ratio for gastric ulcers is $2 \cdot 4: 1$. These ratios are normally relatively constant throughout

TABLE IV

INCIDENCE OF PEPTIC ULCER IN PATIENTS WITH HEPATIC CIRRHOSIS

\begin{tabular}{|c|c|c|c|c|c|c|c|c|}
\hline \multirow[t]{2}{*}{ Series } & \multirow[t]{2}{*}{ Type of Cirrhosis } & \multirow[t]{2}{*}{ Type of Survey } & \multirow{2}{*}{$\begin{array}{l}\text { No. of } \\
\text { Patients }\end{array}$} & \multicolumn{4}{|c|}{ No. with Peptic Ulcer } & \multirow[t]{2}{*}{ Remarks } \\
\hline & & & & $\begin{array}{l}\text { Duodenal } \\
\text { Ulcer }\end{array}$ & $\begin{array}{l}\text { Gastric } \\
\text { Ulcer }\end{array}$ & Total & Total $\%$ & \\
\hline Lipp and Lipsitz (1952) & Alcoholic & $\begin{array}{l}\text { Clinical- } \\
\text { retrospective }\end{array}$ & 1,418 & & & & $3 \cdot 2$ & U.S.veterans \\
\hline Palmer and Brick (1953) & Mainly alcoholic & $\begin{array}{l}\text { Clinical- } \\
\text { prospective }\end{array}$ & 150 & 15 & 7 & 22 & $14 \cdot 6$ & U.S.A. \\
\hline $\begin{array}{l}\text { Swisher, Baker, and } \\
\text { Bennett (1955) }\end{array}$ & Mainly slcoholic & $\begin{array}{l}\text { Radiology- } \\
\text { prospective }\end{array}$ & 419 & 47 & 7 & 54 & $12 \cdot 9$ & U.S. veterans \\
\hline Present series & $\left.\begin{array}{l}\text { Non-alcoholic } \\
\text { Alcoholic }\end{array}\right\}$ & $\begin{array}{l}\text { Clinical- } \\
\text { retrospective }\end{array}$ & $\begin{array}{r}200 \\
55\end{array}$ & $\begin{array}{r}18 \\
3\end{array}$ & $\begin{array}{l}5 \\
2\end{array}$ & $\begin{array}{r}23 \\
5\end{array}$ & $\begin{array}{r}11 \cdot 5 \\
9 \cdot 1\end{array}$ & \\
\hline
\end{tabular}


TABLE V

INCIDENCE OF PEPTIC ULCER IN PATIENTS WITH CIRRHOSIS AND A PORTACAVAL ANASTOMOSIS

\begin{tabular}{|c|c|c|c|c|c|c|}
\hline \multirow[t]{2}{*}{ Series } & \multirow{2}{*}{$\begin{array}{l}\text { No. of } \\
\text { Patients }\end{array}$} & \multicolumn{4}{|c|}{ No. with Peptic Ulcer } & \multirow[t]{2}{*}{ Remarks } \\
\hline & & $\begin{array}{l}\text { Duodenal } \\
\text { Ulcer }\end{array}$ & $\begin{array}{l}\text { Gastric } \\
\text { Ulcer }\end{array}$ & Total & Total $\%$ & \\
\hline $\begin{array}{l}\text { Clarke, Ozeran, Hart, Cruze, and } \\
\text { Crevling (1958) }\end{array}$ & 62 & 3 & 2 & 5 & & Three-quarters U.S. veterans \\
\hline Dubuque, Mulligan, and Neville (1958) & 60 & - & - & 9 & & \\
\hline Ludington (1958) & 8 & 1 & 2 & 3 & & U.S. veterans \\
\hline Wantz and Payne (1961) & 101 & 6 & 3 & 9 & & \\
\hline McDermott, Palazzi, Nardi, and Mondet (1961) & 52 & 4 & 3 & 7 & & \\
\hline Present series & 35 & 4 & 1 & 5 & & \\
\hline Total & 318 & 18 & 11 & 38 & 12 & \\
\hline
\end{tabular}

all age groups, but vary from country to country (Doll, 1952). The previous clinical surveys have mainly originated from the U.S. Veterans Administration which deals almost exclusively with male patients and nearly all these cirrhotic patients are alcoholic (Table IV). Our results suggest that the risk of developing a chronic peptic ulcer is increased in all patients with portal cirrhosis even in the absence of alcoholism. There was no evidence of an increased incidence of peptic ulcer among those of our patients who had had a portacaval anastomosis. The numbers are of course small, but, when combined with previous series (Table $\mathrm{V}$ ), there is an overall incidence of $12 \%$ in 315 cases; this agrees remarkably well with the incidence we found in our patients with portal cirrhosis without a portacaval anastomosis. Thus, the contention that peptic ulceration is increased after this operation has not been confirmed. The extremely high incidence of peptic ulcer in patients with primary biliary cirrhosis has been commented on elsewhere (Sherlock, 1959). We did not find a general depression of gastric secretion in patients with hepatic cirrhosis as was observed by Ostrow et al. (1960) and Bendett et al. (1963). This difference might be explained by the fact that the patients in these two series were alcoholics who are liable to develop gastritis (Palmer, 1954) which is known to be associated with depressed gastric secretion (Bock et al., 1963). We find the main abnormality of gastric secretion in patients with a portacaval anastomosis who had a high basal secretion. This suggests that the stomach of such patients is being persistently stimulated to secrete acid even at rest, for there are presumably a normal number of parietal cells as shown by the normal response to maximum histamine stimulation (Card and Marks, 1960). This contention was supported by the more acid contents of the stomachs of such patients, both when fasting and in response to a standard series of meals which may be considered to be a submaximal stimulus to gastric secretion. These results are compatible with those of Ostrow et al. (1960) who found that cirrhotic patients after a portacaval anastomosis operation had a higher basal secretion and greater response to submaximal histamine stimulation than cirrhotic patients who had not had such an operation. They also subsiantiate the work of Clarke et al. (1958) who found that dogs after a portacaval anastomosis secrete acid urine from a Heidenhain pouch when fasting and after food. On the other hand Bendett et al. (1963) and Clarke et al. (1959a) did not find such changes in patients with a portacaval anastomosis while Gregory (1958) found that dogs with portal obstruction increased their maximum histamine response. We cannot offer any explanation for these discrepancies.

The experiments in dogs suggest that the altered gastric secretion is due to failure of the liver to inactivate a gastric secretogogue of intestinal origin (Clarke et al., 1959b; Kohatsu, Gwaltney, Nagano, and Dragstedt, 1959; Clarke, 1960). Irvine, Duthie, and Waton (1959) suggested that this secretogogue might be histamine derived from the bacterial decarboxylation of dietary histidine, but the failure of oral neomycin to alter the gastric secretory response both of dogs with a portacaval anastomosis (Clarke et al., 1959b) and also one of our patients, makes this suggestion unlikely.

Although the abnormal gastric secretory changes are seen after a portacaval anastomosis, it must be remembered that the incidence of peptic ulcer is just as high in patients with hepatic cirrhosis who have not had this operation so that it is extremely difficult to know whether they are of importance in the genesis of peptic ulcers. A more likely explanation is that the normal mucosal mechanism which prevents the formation of peptic ulcers and seems to be more largely developed in women than men is deranged in liver disease. The high incidence of peptic ulcer in patients with hepatic cirrhosis makes it mandatory to exclude this as a cause of gastrointestinal haemorrhage in such patients.

We would like to thank Professor Sherlock for encouraging us to study her patients. 


\section{REFERENCES}

Atkinson, M., and Henley, K. S. (1955). Levels of intragastric and intraduodenal acidity. Clin. Sci., 14, 1-14.

Baron, J. H. (1963). Studies of basal and peak acid output with an augmented histamine test. Gut, 4, 136-144.

Bendett, R. J., Fritz, H. L., and Donaldson, R. M. Jr. (1963). Gastric acid secretion after parenterally and intragastrically administered histamine in patients with portacaval shunt. New Engl. J. Med., 268, 511-516.

Bock, O. A. A., Richards, W. C. D., and Witts, L. J. (1963). The relationship between acid secretion after augmented histamine stimulation and the histology of the gastric mucosa. Gut, 4, 112-114.

Bruce, J., Card, W. I., Marks, I. N., and Sircus, W. (1959). The rationale of selective surgery in the treatment of duodenal ulcer. J. roy. Coll. Surg. Edinb., 4, 85-104.

Card, W. I., and Marks, I. N. (1960). The relationship between the acid output of the stomach following 'maximal' histamine stimulation and the parietal cell mass. Clin. Sci., 19, 147-163.

Clarke, J. S. (1960). Influence of the liver upon gastric secretion. Amer. J. Med., 29, 740-747.

- Costarella, R., and Ward, S. (1959a). Gastric secretion in the fasting state and after antral stimulation in patients with cirrhosis and with portacaval shunts. Surg. Forum, 9, 417420.

—-, McKissock, P. K., and Cruze, K. (1959b). Studies on the site of origin of the agent causing hypersecretion in dogs with portacaval shunt. Surgery, 46, 48-55.

-, Ozeran, R. S., Hart, J. C., Cruze, K., and Crevling, V. (1958). Peptic ulcer following portacaval shunt. Ann. Surg., 148, 551-566.

Doll, R. (1952). Peptic ulcer. I. Endemiology. In Modern Trends in Gastroenterology, edited by F. Avery Jones, pp. 361-379, 1st series. Butterworth, London.

Dubuque, T. J. Jr., Mulligan, L. V., and Neville, E. C. (1958). Gastric secretion and peptic ulceration in the dog with portal obstruction and portacaval anastomosis. Surg. Forum, 8, 208-211.
Gregory, R. A. (1958). Gastric secretory responses after portal venous ligation. J. Physiol. (Lond.), 144, 123-137.

Grossman, M. I., Kirsner, J. B., and Gillespie, I. E. (1963). Basal and histalog-stimulated gastric secretion in control subjects and in patients with peptic ulcer or gastric cancer. Gastroenterology, 45, 14-26.

Irvine, W. T., Duthie, H. L., and Waton, N. G. (1959). Urinary output of free histamine after a meat meal. Lancet, 1, 1061-1064.

Kay, A. W. (1953). Effect of large doses of histamine on gastric secretion of $\mathrm{HCl}$. An augmented histamine test. Brit. med. J., 2, 77-80.

Kohatsu, S., Gwaltney, J. A., Nagano, K., and Dragstedt, L. R. (1959). Mechanism of gastric hypersecretion following portacaval transposition. Amer. J. Physiol., 196, 841-843.

Koide, S. S., Texter, E. C. Jr., and Borden, C. W. (1958). Perforation of peptic ulcer following paracentesis in patients with cirrhosis. Amer. J. dig. Dis., 3, 24-37.

Lipp, W. F., and Lipsitz, M. H. (1952). The clinical significance of the co-existence of peptic ulcer and portal cirrhosis, with special reference to the problem of massive hemorrhage. Gastroenterology, 22, 181-191.

Ludington, L. G. (1958). A study of 158 cases of esophageal varices. Surg. Gynec. Obstet., 106, 519-526.

McDermott, W. V. Jr., Palazzi, H., Nardi, G. L., and Mondet, A. (1961). Elective portal systemic shunt: an analysis of 237 cases. New Engl. J. Med., 264, 419-427.

Ostrow, J. D., Timmerman, R. J., and Gray, S. J. (1960). Gastric secretion in human hepatic cirrhosis. Gastroenterology, 38 303-313.

Palmer, E. D. (1954). Gastritis: a revaluation. Medicine (Baltimore), 33, 199-290.

- and Brick, I. B. (1953). Sources of upper gastrointestinal hemorrhage in cirrhotic patients with esophageal varices. New Engl. J. Med., 248, 1057-1058.

Sherlock, S. (1959). Primary biliary cirrhosis (Chronic intrahepatic obstructive jaundice). Gastroenterology, 37, 574-586.

Swisher, W. P., Baker, L. A., and Bennett, H. D. (1955). Peptic ulcer in Laennec's cirrhosis. Amer. J. dig. Dis., 22, 291-294.

Wantz, G. E., and Payne, M. A. (1961). Experience with portacaval shunt for portal hypertension. New Engl. J. Med., 265, 721-728, 